Keywords: myeloid leukaemia; lung cancer; familial clustering; mice; ionising radiation; space radiation exposure; high-energy beam

\title{
High-energy particle beam and gamma radiation exposure, familial relatedness and cancer in mice
}

\author{
Pavel Chernyavskiy ${ }^{1}$, Elijah F Edmondson ${ }^{2,3}$, Michael M Weil ${ }^{2}$ and Mark P Little ${ }^{\star, 1}$ \\ ${ }^{1}$ Radiation Epidemiology Branch, National Cancer Institute, Bethesda, MD 20892-9778, USA; ${ }^{2}$ Colorado State University, Fort \\ Collins, CO 80523, USA and ${ }^{3}$ Frederick National Laboratory for Cancer Research, National Cancer Institute, Fort Detrick, Frederick, \\ MD 21702, USA
}

Background: Some highly penetrant familial cancer syndromes exhibit elevated leukaemia risk, and there is evidence for familial clustering of lung cancer and other common cancers. Lung cancer and leukaemia are strongly radiogenic, but there are few indications that high-energy beam irradiation is markedly more effective than lower-energy radiation.

Methods: We used a Cox model with familially structured random effects to assess 16 mortality end points in a group of 1850 mice in 47 families maintained in a circular-breeding scheme, exposed to accelerated $\mathrm{Si}$ or Fe ions (0.4 Gy) or ${ }^{137} \mathrm{Cs}$ gamma rays (3 Gy).

Results: There is periodicity in the effect of familial relatedness, which is most pronounced for pulmonary adenoma, Harderiangland adenoma, Harderian-gland tumour, ectodermal tumour, pulmonary adenocarcinoma and hepatocellular carcinoma $(P=0.0001 / 0.0003 / 0.0017 / 0.0035 / 0.0257 / 0.0340$, respectively) with families that are 3-4 generations apart most strongly correlated; myeloid leukaemia also exhibited a striking periodic correlation structure. The relative risks of high-energy $\mathrm{Si}$ or Fe ions are not significantly different and are less than for ${ }^{137} \mathrm{Cs}$ gamma-rays for most end points at the doses used.

Conclusions: There is periodicity in the effect of familial relatedness for various cancer sites. The effects per unit dose of high-energy charged particle beams are no higher than ninefold those of lower-energy gamma radiation.

There are a number of highly penetrant familial cancer syndromes, in particular Cowden syndrome, familial adenomatous polyposis, hereditary nonpolyposis colon cancer, Li-Fraumeni syndrome and multiple endocrine neoplasia $1+2$ (Nagy et al, 2004). Myeloid leukaemia is associated with a number of highly penetrant genetic syndromes, in particular Fanconi anemia, Bloom syndrome, ataxiatelangiectasia, Li-Fraumeni syndrome and neurofibromatosis type 1 (Seif, 2011). Lung cancer is also associated with Li-Fraumeni syndrome and certain other rare germline mutations (Gonzalez et al, 2009; Gazdar et al, 2014). Possibly associated with this, there is evidence for familial clustering of certain common cancers, such as the lung, breast and colon (McDuffie, 1991; Borch-Johnsen et al, 1994) although not for myeloid leukaemia (Nickels et al, 2013).
There is abundant epidemiological evidence that most types of cancer are inducible by ionising radiation exposure (United Nations Scientific Committee on the Effects of Atomic Radiation (UNSCEAR), 2008). Lung cancer and myeloid leukaemia are among the most strongly radiogenic human tumours (Egawa et al, 2012; Hsu et al, 2013; United Nations Scientific Committee on the Effects of Atomic Radiation (UNSCEAR), 2008). Leukaemia was the first cancer type to be observed in excess among the survivors of the atomic bombings of Hiroshima and Nagasaki (Folley et al, 1952), and radiation-associated excess leukaemia is seen in most major radiation-exposed groups (United Nations Scientific Committee on the Effects of Atomic Radiation (UNSCEAR), 2008), even at very low doses/dose rates (Pearce et al, 2012; Kendall

*Correspondence: Dr MP Little; E-mail mark.little@nih.gov

Received 18 March 2017; revised 12 April 2017; accepted 24 April 2017; published online 23 May 2017

(C) 2017 Cancer Research UK. All rights reserved 0007 - 0920/17 
et al, 2013; Leuraud et al, 2015). However, the effects of highcharge, high-energy (HZE) and high linear energy transfer (LET) ions found in the space environment on cancer risks are not well understood. There is almost no human cancer data, although there is limited information on cataract and other ocular abnormalities after astronaut space-radiation exposure (Durante and Cucinotta, 2008; Chylack et al, 2009, 2012). In the absence of human exposure data on HZE ion radiation, results from in vitro (Sridharan et al, 2015) and in vivo (animal) studies (Bielefeldt-Ohmann et al, 2012) utilising simulated space radiation are a key component to risk modelling. A study of $\mathrm{C} 3 \mathrm{H} / \mathrm{HeNCrl}$ mice irradiated with $300 \mathrm{MeV}$ nucleon ${ }^{-1}$ (n) ${ }^{28} \mathrm{Si}$ ions (HZE-Si), $600 \mathrm{MeV} \mathrm{n}^{-1}{ }^{56} \mathrm{Fe}$ ions (HZE-Fe), protons or ${ }^{137} \mathrm{Cs}$ gamma rays did not find that HZE-Fe/HZE-Si were substantially more effective than ${ }^{137} \mathrm{Cs}$ gamma ray or proton radiation at inducing acute myeloid leukaemia, although rates of hepatocellular carcinoma were substantially higher after HZE ion irradiation than after ${ }^{137} \mathrm{Cs}$ gamma ray or proton irradiation (Weil et al, 2014).

In this paper, we shall analyse lung cancer, myeloid leukaemia and a variety of other mortality end points in a group of mice exposed to HZE-Fe, HZE-Si and ${ }^{137} \mathrm{Cs}$ gamma ray radiation. The mice are genetically heterogeneous and maintained as 'families' in which progeny are more closely related to one another than to mice in other families. As such, it is more like an outbred population such as humans than are most strains of animals used experimentally. The mice are maintained in a circular-breeding scheme derived from eight founder strains with substantial differences in radiogenic cancer susceptibility. For example, the $C 57 B L / 6$ strain is susceptible to radiation-induced lymphoma but not to radiation-induced AML, whereas the $\mathrm{C} 3 \mathrm{H}$ strain is susceptible to radiation-induced AML (Storer et al, 1988). We are particularly interested in assessing variations in risk associated with type of radiation exposure (HZE-Fe vs HZE-Si vs ${ }^{137} \mathrm{Cs}$ gamma) and with the degree of familial relatedness.

\section{DATA AND METHODS}

\section{Data}

Animals. HS/Npt mice are a genetically heterogeneous stock of mice descended from matings of eight inbred founder strains $(A / J$, $A K R / J, B A L B / c J, C 3 H / H e J, C 57 B L / 6 J, C B A / J, D B A / 2 J$ and $L P / J)$ that is propagated using a circular-breeding design (Hitzemann et al, 1994). The HS/Npt stock has been continuously maintained (Hitzemann et al, 1994) and was at generation 70 at the time the work described here was initiated, so the mice used in the study were generation 71 . The heterogeneous stocks were developed to map quantitative trait loci (QTL). The multi-generation quasirandom mating for $\mathrm{HS} / \mathrm{Npt}$ results in a high density of recombinations of the original genomes, and the resulting reduction in linkage disequilibrium results in a QTL map precision of $\sim 2-3 \mathrm{Mb}$ for a QTL accounting for about $5 \%$ of a trait variance.

In the circular-breeding design, the stock is maintained as a group of 'families' (Crabbe et al, 1983). At each successive generation, a male mouse from family 1 is bred to a female mouse from family 2 (with the resulting offspring being deemed to be in family 2 in the next generation), a male mouse from family 2 is bred to a female mouse from family 3 (with the resulting offspring being deemed to be in family 3 in the next generation) and so on. In this study, a family consisted of the offspring from the harem mating of one male and two female mice from the same family at generation 71 . The mice were bred at irregular intervals, as needs arose in various experiments. There are a total of 47 families.

Irradiation. Male and female mice at 7-12 weeks of age were sham irradiated or irradiated with either $0.4 \mathrm{~Gy}$ of HZE ions $\left(240 \mathrm{MeV} \mathrm{n}^{-128} \mathrm{Si}\right.$ ions or $\left.600 \mathrm{MeV} \mathrm{n}^{-156} \mathrm{Fe}\right)$ or $3.0 \mathrm{~Gy}$ of ${ }^{137} \mathrm{Cs}$ gamma rays. Mice from all groups were shipped together to the Brookhaven National Laboratory (BNL) for radiation exposures or sham irradiation. Upon arrival, mice were acclimatised for at least 2 days before being irradiated with $0.4 \mathrm{~Gy}$ of HZE ions at the NASA Space Radiation Laboratory or $3 \mathrm{~Gy}$ of ${ }^{137} \mathrm{Cs}$ gamma rays at the Medical Research Center. The doses were chosen to maximise tumour yield for each radiation type, based on the findings from earlier studies (summarised in Bielefeldt-Ohmann et al, 2012). The $0.4 \mathrm{~Gy}$ dose was chosen based on the dose response for HZE-ion induced Harderian-gland tumours in $\mathrm{B}_{6} \mathrm{CF}_{1}$ mice, $1 \mathrm{GeV} \mathrm{n}{ }^{-156} \mathrm{Fe}$ ion-induced mammary tumours in Sprague-Dawley rats and $1 \mathrm{GeV} \mathrm{n}{ }^{-1}{ }^{56} \mathrm{Fe}$ ion-induced hepatocellular carcinomas in CBA mice. (The $\mathrm{C} 3 \mathrm{H}$ data were not available at the time the experiment started.) All models showed a turnover in the dose-response curve at $\sim 0.4-0.5$ Gy. For gamma rays, a maximally leukaemogenic dose of $3 \mathrm{~Gy}$ was used. A total of 934 male and 916 female mice were selected as described above and split into an irradiated and shamirradiated (control) group. Approximately equal numbers of males and females were used for each exposure type (309/304 male/ female unirradiated, $151 / 157$ male/female exposed to ${ }^{28} \mathrm{Si}$ ions, $161 / 153 \mathrm{male} / \mathrm{female}$ exposed to ${ }^{56} \mathrm{Fe}$ ions, 313/302 male/female exposed to gamma rays). There were a range of 16-62 mice (mean $39.4(=1850 / 47))$ per family; the range of family sizes was 4-22 (mean 13.0) in the unexposed animals, 6-24 (mean 13.2) in the HZE-exposed mice and 6-21 (mean 13.1) in the gamma-exposed mice. Care was taken to ensure that each family was distributed equally among the exposure types. Control mice were shamirradiated at BNL under the same conditions as the irradiated groups. The mice were not anaesthetised during irradiation or any other part of the study. Further details are provided elsewhere (Weil et al, 2009, 2014).

Tumour detection. Following irradiation, the mice were monitored for cancer development. Moribund mice, mice with palpable tumours and mice that reached 800 days of age were killed and necropsied. All tumours were classified by histopathology. Summary data are presented in Table 1.

Ethics statement. All animal work was approved by the Institutional Animal Care and Use Committee at Colorado State University under protocol 11-3027A. The facility is Association for Assessment and Accreditation of Laboratory Animal Care accredited. Killing was by carbon dioxide inhalation.

Statistical methods. We chose all end points with numbers of deaths $>5 \%$ of the total cohort $(n=1850)$. These comprise the 16 causes of death listed in Table 1 . We split these end points into two, comprising a principal group of eight end points, with details given in the main part of the paper, namely: (1) solid cancer, (2) lymphoma, (3) myeloid leukaemia, (4) soft tissue sarcoma, (5) pulmonary adenocarcinoma, (6) pulmonary adenoma, (7) hepatocellular carcinoma and (8) hepatocellular adenoma. Information on the remaining eight auxiliary end points is given in Supplementary Material, comprising: (1) all death, (2) all cancer, (3) mesodermal tumour, (4) endodermal tumour, (5) ectodermal tumour, (6) unilateral Harderian-gland tumour, (7) Harderiangland adenoma and (8) metastatic tumour. Supplementary Figure S1 depicts the distribution of attained age in days for all deaths by radiation exposure type, regardless of end point. Supplementary Figure S2 plots the distribution of age at death, in days, by radiation exposure type for the 16 end points considered in this study.

A Cox proportional-hazards model (Cox, 1972) was used for modelling mouse survival data. Cox models assume that, conditional on some set of covariate values and the attained time (age) at event onset, individual survival times are mutually independent (e.g., Ripatti and Palmgren, 2000). Because mice were 
Table 1. Summary of data

\begin{tabular}{|c|c|c|c|c|c|}
\hline End point & Unirradiated & HZE-Fe & HZE-Si & Gamma & Total \\
\hline Mouse days & 400206 & 184404 & 183953 & 320142 & 1088705 \\
\hline Mice & 613 & 314 & 308 & 615 & 1850 \\
\hline All death & 489 & 278 & 270 & 575 & 1612 \\
\hline Any cancer & 436 & 248 & 240 & 531 & 1455 \\
\hline $\begin{array}{l}\text { Mesodermal } \\
\text { tumour }\end{array}$ & 273 & 125 & 137 & 339 & 874 \\
\hline $\begin{array}{l}\text { Endodermal } \\
\text { tumour }\end{array}$ & 281 & 158 & 142 & 270 & 851 \\
\hline All solid cancer & 222 & 159 & 138 & 235 & 754 \\
\hline All lymphomas & 204 & 85 & 90 & 203 & 582 \\
\hline $\begin{array}{l}\text { Pulmonary } \\
\text { adenocarcinoma }\end{array}$ & 115 & 60 & 64 & 110 & 349 \\
\hline $\begin{array}{l}\text { Ectodermal } \\
\text { tumour }\end{array}$ & 33 & 85 & 76 & 125 & 319 \\
\hline $\begin{array}{l}\text { Hepatocellular } \\
\text { adenoma }\end{array}$ & 94 & 68 & 58 & 94 & 314 \\
\hline $\begin{array}{l}\text { Hepatocellular } \\
\text { carcinoma }\end{array}$ & 85 & 57 & 43 & 66 & 251 \\
\hline $\begin{array}{l}\text { Pulmonary } \\
\text { adenoma }\end{array}$ & 78 & 31 & 25 & 87 & 221 \\
\hline $\begin{array}{l}\text { Harderian gland } \\
\text { adenoma }\end{array}$ & 21 & 67 & 54 & 77 & 219 \\
\hline $\begin{array}{l}\text { Unilateral } \\
\text { Harderian gland } \\
\text { tumour }\end{array}$ & 19 & 50 & 49 & 74 & 192 \\
\hline $\begin{array}{l}\text { Soft tissue } \\
\text { sarcoma }\end{array}$ & 50 & 28 & 29 & 29 & 136 \\
\hline $\begin{array}{l}\text { Myeloid } \\
\text { leukaemia }\end{array}$ & 10 & 5 & 13 & 96 & 124 \\
\hline $\begin{array}{l}\text { Metastatic } \\
\text { tumour }\end{array}$ & 35 & 24 & 17 & 33 & 109 \\
\hline \multicolumn{6}{|c|}{$\begin{array}{l}\text { Abbreviations: } \mathrm{HZE}-\mathrm{Fe}=\text { high-charge, high-energy }{ }^{56} \mathrm{Fe} \text { ions; } \mathrm{HZE}-\mathrm{Si}=\text { high-charge, high- } \\
\text { energy }{ }^{28} \mathrm{Si} \text { ions. Shown are all tumour end points in which }>5 \% \text { of the } n=1850 \text { animals } \\
\text { developed a malignancy. }\end{array}$} \\
\hline
\end{tabular}

kept in families, it is reasonable to assume that individual survival times are correlated within family, possibly due to unobserved familial characteristics that may have allowed certain families to fare better against specific types of radiation. We shall therefore use Cox models with a random effect (Vaupel et al, 1979; Aalen, 1988) to adjust for familial heterogeneity in the study population, assuming that the risk of some end point is given by:

$$
h(t)=h_{0}(t) \exp (X \beta+Z u)
$$

where $h_{0}(t)$ is the (unspecified) baseline hazard function, $X$ and $Z$ are the respective design matrices for fixed and random effects, $\beta$ is the vector of time-independent fixed-effects coefficients and $u$ is the vector of random effect coefficients. We assume that random effects $u$ have a multivariate normal distribution with mean 0 , and a diagonal variance-covariance matrix $\Sigma$. We assume a random adjustment by mouse family to account for correlation of survival times within family and heterogeneity in survival times between families. The distribution (over the 47 families) of the random effects are plotted for each of the main eight end points in Figure 1 and for the eight auxiliary end points in Supplementary Figure S4. In some models, we also assume an additional family random effect nested within radiation type (unirradiated/HZE/gamma) or alternatively an additional radiation-type random effect nested within family. For example, in the case of the latter model (radiation-type nested within the effect for family) we assume that in stratum $i$ with family $j$ and radiation type $k$, the risk is given by:

$$
h\left(t_{i j k}\right)=h_{0}\left(t_{i j k}\right) \exp \left(X_{i j k} \beta+\varepsilon_{j}+\eta_{j k}\right)
$$

where we assume that $\varepsilon_{j} \sim N\left(0, \tau_{1}^{2}\right), \eta_{j k} \sim N\left(0, \tau_{2}^{2}\right)$ and $\varepsilon_{j}$ and $\eta_{j k}$ are mutually independent. Further statistical details are given in Supplementary Material.

The circular-breeding scheme has the property that families with index numbers closest together are the most closely related, with extreme indices $(1,47)$ also being most closely related. Thus we may consider the difference in family indices as a proxy of familial 'distance' or 'dissimilarity' (hereafter referred to as $m$ ). We assessed autocorrelations of family random effects in relation to $m$, so that we estimate $\operatorname{corr}\left(\varepsilon_{j}, \varepsilon_{j+m}\right)$. The autocorrelation plots for the eight main end points are given in Figure 2 and for the eight auxiliary end points in Supplementary Figure S5. The $P$-values associated with Fisher $g$-test of periodicity (Fisher, 1929) are also given in these figures, evaluated using autocorrelations with $m=1, \ldots, 23$; for values of $m>23$, the autocorrelations are mirrored, and so we exclude them from the test.

Cox frailty models were fitted using the coxme package (Therneau, 2015) in $\mathrm{R}$ ( $\mathrm{R}$ Project version 3.2.2, 2015). Table 2 presents summary goodness-of-fit statistics for various models fitted to each of the eight main end points outlined above; Supplementary Table S1 gives the analogous model fit information for the eight auxiliary end points. We employ the Akaike information criterion (AIC) (Akaike, 1973, 1981) and the Bayesian information criterion (BIC) (Schwarz, 1978) to select an optimal model. Both criteria penalise the likelihood for the numbers of parameters fitted, and in the case of the BIC, this penalty is also a function of sample size. We shall particularly emphasise the AIC, as we are not in the situation where the true model is known.

Fixed effects in each model consisted of radiation-exposure type, mouse gender and their interaction. Relative risk (RR) (= hazard ratio) estimates for the main eight end points are presented in Tables 3 and 4; this information is also given for the eight auxiliary end points in Supplementary Tables S2 and S3. The unirradiated group of mice was used as the reference group for exposure type, whereas female mice were used as the reference group for sex effects per radiation group. In addition to RR estimates, Tables 3 and 4 and Supplementary Tables S2 and S3 contain estimates for the estimated standard deviation (s.d.) of mouse family random effect by family and by radiation group nested within the family (using the structure indicated for model 13 in Table 2, Supplementary Table S1). Tests of improvement in fit were generally based on the likelihood ratio test (Cox and Hinkley, 1974). For example, this test was used to assess significance of difference between the two HZE effects (HZE-Si and $\mathrm{HZE}-\mathrm{Fe}$ ) and tests for interaction between sex and exposure type. In cases where the tests are at the boundary of the parameter space, appropriate corrections are made (Self and Liang, 1987).

\section{RESULTS}

Table 2 and Supplementary Table S1 demonstrate that the optimal model (i.e., with smallest AIC) for most end points was model 13, which incorporated fixed-effect adjustments with interactions between radiation group and sex (i.e., allowing for each combination of radiation group and sex), a random intercept per family and a random effect for radiation group nested within family. For myeloid leukaemia, hepatocellular carcinoma and hepatocellular adenoma, a simpler model (model 5) was indicated, without interactions between sex and radiation group, and using a simpler per-family non-nested random effect structure (Table 2).

For all end points except unilateral Harderian-gland tumour, the improvement in fit obtained by adding a random family effect was generally highly statistically significant $(P<0.05$, but for many 

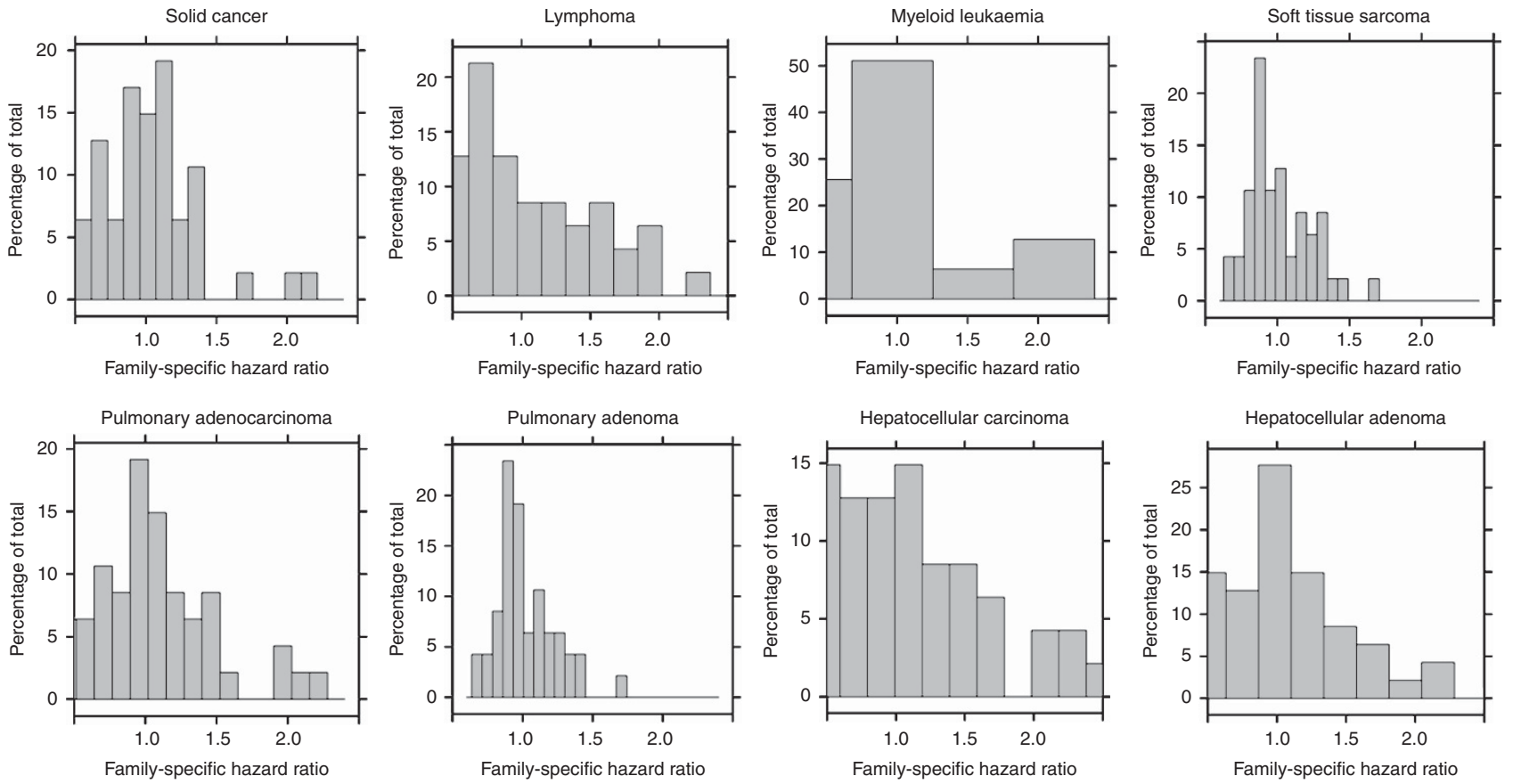

Figure 1. Distribution of estimated family-specific relative risks for deaths and various cancer end points. A full colour version of this figure is available at the British Journal of Cancer journal online.
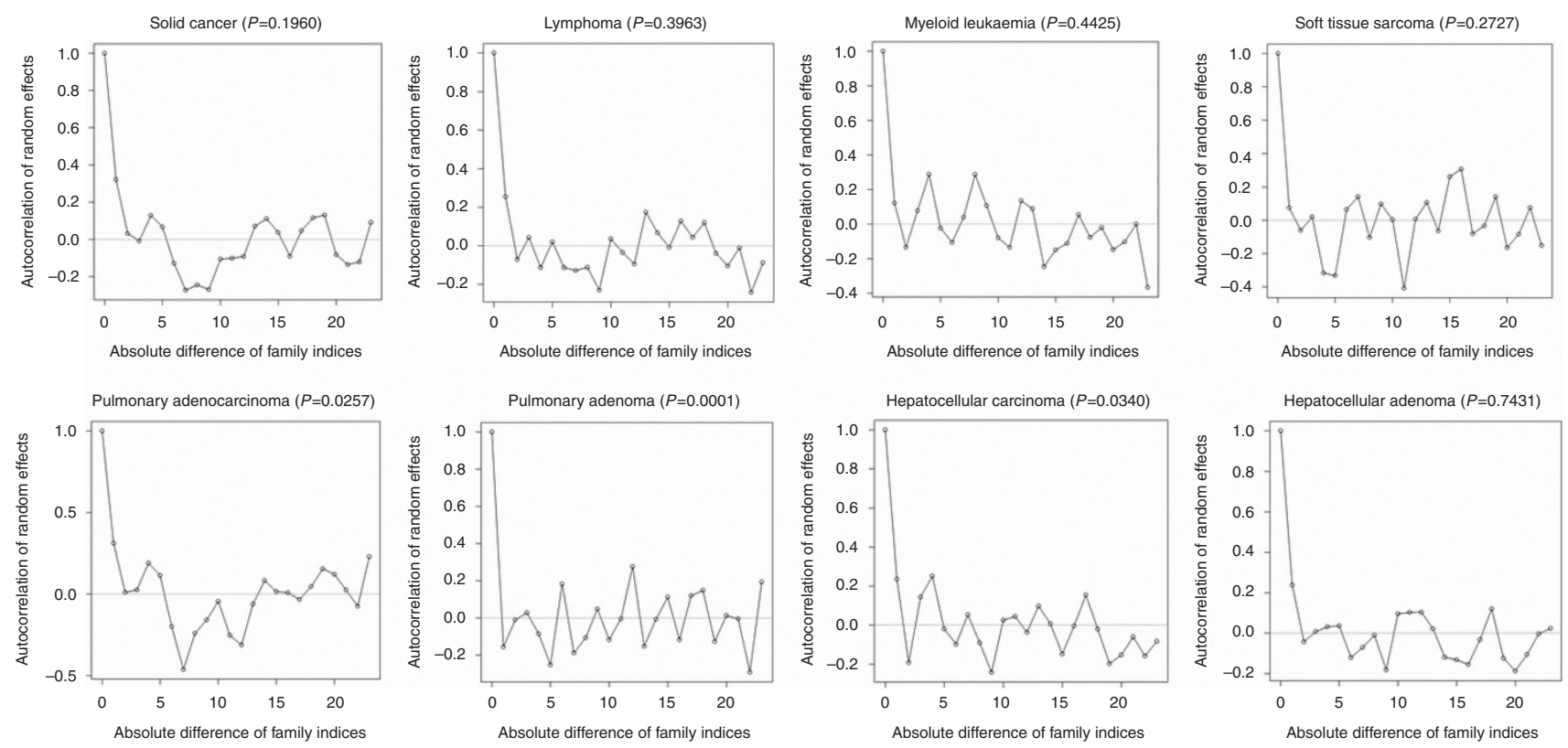

Figure 2. Autocorrelation of family-specific random effects for all deaths and various cancer end points in relation to distance apart of the family index number. Fisher $g$-test of periodicity $P$-values are given in panel legends.

end points $P<0.0001$ ) (Tables 3 and 4 , Supplementary Tables S2 and S3). For a few end points (lymphoma, all death, all cancer, mesodermal tumours), there is also statistically significant improvement in fit by adding the random effect for radiation group nested within family to a model with simple per-family random effect (Tables 3 and 4, Supplementary Tables S2 and S3). Reinforcing this, Supplementary Figure S3 shows the marked variability among family median survival times within the same type of exposure, further suggesting the need for a random effect to account for variation in survival times due to family and the correlation of survival times within family.

For many end points, in particular solid cancer, lymphoma, all death, all cancer, endodermal tumour, ectodermal tumour, unilateral Harderian-gland tumour, Harderian-gland adenoma and metastatic tumour, the interaction between mouse sex and radiation exposure was statistically significant $(P<0.05$; Tables 3 and 4, Supplementary Tables S2 and S3). For example, the all cancer RR for gamma-exposure in relation to the unirradiated group for male mice was 2.22 (95\% CI 1.83, 2.70), compared with 3.93 (95\% CI $3.15,4.91)$ for female mice, thereby somewhat offsetting the elevated risks for this sex in the baseline unirradiated group $(\mathrm{RR}=1.54,95 \% \mathrm{CI} 1.27,1.86)$ (Supplementary Table S2). There were similar discrepancies in the sex-specific RR for other radiation types (HZE-Fe, HZE-Si) and end points other than myeloid leukaemia (Tables 3 and 4, Supplementary Tables S2 and S3). In all cases, the model that allows for separate effects of 
Table 2. Akaike information criterion (AIC) and Bayesian information criterion (BIC) for various models, by disease end point

\begin{tabular}{|c|c|c|c|c|c|c|c|c|c|}
\hline \multirow[b]{2}{*}{$\begin{array}{l}\text { Model } \\
\text { no. }\end{array}$} & \multirow[b]{2}{*}{ Model fitted } & \multicolumn{8}{|c|}{$\mathrm{AIC} / \mathrm{BIC}$} \\
\hline & & $\begin{array}{l}\text { Solid } \\
\text { cancer }\end{array}$ & Lymphoma & $\begin{array}{l}\text { Myeloid } \\
\text { leukaemia }\end{array}$ & $\begin{array}{l}\text { Soft } \\
\text { tissue } \\
\text { sarcoma }\end{array}$ & $\begin{array}{l}\text { Pulmonary } \\
\text { adeno- } \\
\text { carcinoma }\end{array}$ & $\begin{array}{l}\text { Pulmonary } \\
\text { adenoma }\end{array}$ & $\begin{array}{l}\text { Hepato- } \\
\text { cellular } \\
\text { carcinoma }\end{array}$ & $\begin{array}{l}\text { Hepato- } \\
\text { cellular } \\
\text { adenoma }\end{array}$ \\
\hline 1 & Random effect per family & $\begin{array}{l}10029.08 / \\
10166.99\end{array}$ & $\begin{array}{l}7725.94 / \\
7876.65\end{array}$ & \begin{tabular}{|l|}
$1735.53 /$ \\
1798.68
\end{tabular} & $\frac{1768.49 /}{1803.94}$ & $\begin{array}{l}4605.76 / \\
4711.13\end{array}$ & \begin{tabular}{|l|}
$2956.09 /$ \\
3002.30
\end{tabular} & $\begin{array}{l}3164.28 / \\
3273.67\end{array}$ & $\begin{array}{l}4063.10 / \\
4181.79\end{array}$ \\
\hline 2 & Sex fixed effect & $\begin{array}{l}10074.12 / \\
10078.74\end{array}$ & $\begin{array}{l}7838.59 / \\
7842.96\end{array}$ & \begin{tabular}{|l}
$1738.98 /$ \\
1741.80
\end{tabular} & $\begin{array}{l}1775.23 / \\
1778.14 \\
\end{array}$ & $\begin{array}{l}4576.12 / \\
4579.97\end{array}$ & \begin{tabular}{|l|}
$2927.38 /$ \\
2930.78
\end{tabular} & $\begin{array}{l}3149.94 / \\
3153.46\end{array}$ & \begin{tabular}{|l|}
$4074.23 /$ \\
4077.98
\end{tabular} \\
\hline 3 & Sex fixed effect + random effect per family & $\begin{array}{l}10012.15 / \\
10154.55\end{array}$ & $\begin{array}{l}7727.74 / \\
7882.91\end{array}$ & $\begin{array}{l}1718.69 / \\
1781.47\end{array}$ & $\begin{array}{l}1770.03 / \\
1807.94\end{array}$ & $\begin{array}{l}4533.33 / \\
4643.26\end{array}$ & $\begin{array}{l}2921.12 / \\
2971.43\end{array}$ & $\begin{array}{l}3075.46 / \\
3189.64\end{array}$ & $\begin{array}{l}3992.58 / \\
4115.33\end{array}$ \\
\hline 4 & $\begin{array}{l}\text { Fixed effects of radiation group } \\
\text { (unirradiated, HZE-Fe, HZE-Si, } \\
\text { gamma) }+ \text { sex }\end{array}$ & $\begin{array}{l}9991.69 / \\
10010.19\end{array}$ & $\begin{array}{l}7787.71 / \\
7805.18\end{array}$ & \begin{tabular}{|l|}
$1591.92 /$ \\
$\mathbf{1 6 0 3 . 2 0}$ \\
\end{tabular} & $\begin{array}{l}1774.73 / \\
1786.38\end{array}$ & $\begin{array}{l}4554.85 / \\
4570.27 \\
\end{array}$ & $\begin{array}{l}2897.29 / \\
\mathbf{2 9 1 0 . 8 9} \\
\end{array}$ & $\begin{array}{l}3133.64 / \\
\mathbf{3 1 4 7 . 7 4} \\
\end{array}$ & $\begin{array}{l}4042.99 / \\
4057.98 \\
\end{array}$ \\
\hline 5 & $\begin{array}{l}\text { Fixed effects of radiation group } \\
\text { (unirradiated, HZE-Fe, HZE-Si, } \\
\text { gamma) }+ \text { sex }+ \text { random effect per family }\end{array}$ & $\begin{array}{l}9926.82 / \\
10085.05\end{array}$ & $\begin{array}{l}7656.06 / \\
7829.51\end{array}$ & $\frac{1554.98 /}{1639.80}$ & $\begin{array}{l}1768.92 / \\
1816.89\end{array}$ & $\begin{array}{l}4509.37 / \\
4633.05\end{array}$ & \begin{tabular}{|l}
$2889.17 /$ \\
2954.76
\end{tabular} & $\frac{3058.57 /}{3183.48}$ & $\frac{3960.22 /}{4094.92}$ \\
\hline 6 & $\begin{array}{l}\text { Fixed effects of radiation group } \\
\text { (unirradiated, HZE-Fe, HZE-Si, } \\
\text { gamma) + sex + random effect per } \\
\text { radiation group (unirradiated, combined } \\
\text { HZE, gamma), and random effect per } \\
\text { family nested within radiation group } \\
\text { (unirradiated, combined HZE, gamma) }\end{array}$ & $\begin{array}{l}9950.18 / \\
10222.97\end{array}$ & $\begin{array}{l}7666.10 / \\
8036.32\end{array}$ & $\begin{array}{l}1571.39 / \\
1672.11\end{array}$ & $\begin{array}{l}1772.44 / \\
1822.05\end{array}$ & $\begin{array}{l}4518.31 / \\
4733.88\end{array}$ & $\begin{array}{l}2884.85 / \\
3009.99\end{array}$ & $\begin{array}{l}3090.79 / \\
3292.38\end{array}$ & $\begin{array}{l}3998.21 / \\
4220.52\end{array}$ \\
\hline 7 & $\begin{array}{l}\text { Fixed effects of radiation group } \\
\text { (unirradiated, HZE-Fe, HZE-Si, } \\
\text { gamma) } \times \text { sex }\end{array}$ & $\begin{array}{l}9984.09 / \\
10016.47\end{array}$ & $\begin{array}{l}7785.75 / \\
7816.32\end{array}$ & $\begin{array}{l}1594.63 / \\
1614.37\end{array}$ & $\begin{array}{l}1779.54 / \\
1799.93\end{array}$ & $\begin{array}{l}4559.10 / \\
4586.08\end{array}$ & $\begin{array}{l}2900.47 / \\
2924.26\end{array}$ & $\begin{array}{l}3136.29 / \\
3160.97\end{array}$ & $\begin{array}{l}4046.90 / \\
4073.15\end{array}$ \\
\hline 8 & $\begin{array}{l}\text { Fixed effects of radiation group } \\
\text { (unirradiated, HZE-Fe, HZE-Si, } \\
\text { gamma) } \times \text { sex }+ \text { random effect per family }\end{array}$ & $\begin{array}{l}9918.96 / \\
10091.06\end{array}$ & $\begin{array}{l}\text { 7652.83/ } \\
7839.71\end{array}$ & $\begin{array}{l}1557.36 / \\
1650.82\end{array}$ & $\begin{array}{l}1773.26 / \\
1831.29\end{array}$ & $\begin{array}{l}4513.30 / \\
4648.64\end{array}$ & $\begin{array}{l}\text { 2892.05/ } \\
2968.49\end{array}$ & $\begin{array}{l}3060.29 / \\
3196.07\end{array}$ & $\begin{array}{l}3964.44 / \\
4110.22\end{array}$ \\
\hline 9 & $\begin{array}{l}\text { Fixed effects of radiation group } \\
\text { (unirradiated, HZE-Fe, HZE-Si, } \\
\text { gamma) } \times \text { sex }+ \text { random effect per } \\
\text { radiation group (unirradiated, combined } \\
\text { HZE, gamma), and random effect per } \\
\text { family nested within radiation group } \\
\text { (unirradiated, combined HZE, gamma) }\end{array}$ & $\begin{array}{l}9938.86 / \\
10233.23\end{array}$ & $\begin{array}{l}7665.13 / \\
8046.25\end{array}$ & $\begin{array}{l}1573.76 / \\
1683.51\end{array}$ & $\begin{array}{l}1776.60 / \\
1840.15\end{array}$ & $\begin{array}{l}4521.04 / \\
4752.86\end{array}$ & $\begin{array}{l}2888.03 / \\
3022.66\end{array}$ & $\begin{array}{l}3091.98 / \\
3306.63\end{array}$ & $\begin{array}{l}4002.48 / \\
4234.60\end{array}$ \\
\hline 10 & $\begin{array}{l}\text { Fixed effects of radiation group } \\
\text { (unirradiated, combined HZE, } \\
\text { gamma) } \times \text { sex }\end{array}$ & $\begin{array}{l}9984.40 / \\
10007.53 \\
\end{array}$ & $\begin{array}{l}7781.76 / \\
7803.59 \\
\end{array}$ & $\begin{array}{l}1593.79 / \\
1607.89\end{array}$ & $\begin{array}{l}1775.69 / \\
1790.26\end{array}$ & $\begin{array}{l}4555.98 / \\
4575.26\end{array}$ & $\begin{array}{l}2899.04 / \\
2916.03\end{array}$ & $\begin{array}{l}3136.97 / \\
3154.60\end{array}$ & $\begin{array}{l}4045.18 / \\
4063.93\end{array}$ \\
\hline 11 & $\begin{array}{l}\text { Fixed effects of radiation group } \\
\text { (unirradiated, combined HZE, } \\
\text { gamma) } \times \text { sex }+ \text { random effect per family }\end{array}$ & \begin{tabular}{|l|}
$9917.02 /$ \\
10081.25
\end{tabular} & $\begin{array}{l}7648.99 / \\
7827.17\end{array}$ & \begin{tabular}{|l}
$1558.54 /$ \\
1645.11
\end{tabular} & $\begin{array}{l}1769.93 / \\
1820.79\end{array}$ & $\begin{array}{l}4510.19 / \\
4637.95\end{array}$ & \begin{tabular}{|l|}
$2890.82 /$ \\
2959.98
\end{tabular} & $\begin{array}{l}3060.25 / \\
3189.50\end{array}$ & \begin{tabular}{|l}
$3960.62 /$ \\
4099.64
\end{tabular} \\
\hline 12 & $\begin{array}{l}\text { Fixed effects of radiation group } \\
\text { (unirradiated, combined HZE, } \\
\text { gamma) } \times \text { sex }+ \text { random effects of } \\
\text { radiation group (unirradiated, combined } \\
\text { HZE, gamma) + random effects of family } \\
\text { nested within radiation group } \\
\text { (unirradiated, combined HZE, gamma) }\end{array}$ & \begin{tabular}{|l|}
$9937.37 /$ \\
10227.21
\end{tabular} & $\begin{array}{l}7661.38 / \\
8034.07\end{array}$ & \begin{tabular}{|l}
$1573.77 /$ \\
1676.17
\end{tabular} & $\begin{array}{l}1773.25 / \\
1827.35\end{array}$ & $\begin{array}{l}4518.19 / \\
4742.32\end{array}$ & $\begin{array}{l}2886.20 / \\
3016.38\end{array}$ & $\begin{array}{l}3093.40 / \\
3300.29\end{array}$ & $\begin{array}{l}3999.55 / \\
4227.10\end{array}$ \\
\hline 13 & $\begin{array}{l}\text { Fixed effects of radiation group } \\
\text { (unirradiated, combined HZE, } \\
\text { gamma) } \times \text { sex }+ \text { random effects of } \\
\text { family }+ \text { random effects of radiation group } \\
\text { (unirradiated, combined HZE, gamma) } \\
\text { nested within family }\end{array}$ & $\frac{9916.26 /}{10101.55}$ & $\frac{7637.89 /}{7914.69}$ & $\begin{array}{l}1558.55 / \\
1645.16\end{array}$ & $\begin{array}{l}1769.93 / \\
1820.92\end{array}$ & $\frac{4504.35 /}{4693.10}$ & $\frac{2884.71 /}{3014.21}$ & $\begin{array}{l}3060.26 / \\
3189.73\end{array}$ & $\begin{array}{l}3960.62 / \\
4099.91\end{array}$ \\
\hline
\end{tabular}

HZE-Fe and HZE-Si did not yield significant improvement in fit over a model where the effects of these two types of radiation were constrained to be equal $(P>0.1$; Tables 3 and 4, Supplementary Tables S2 and S3).

Risks for gamma exposure (relative to the unexposed) for myeloid leukaemia are particularly high, 24.07 (95\% CI 9.62, 60.24) for males, 11.17 (95\% CI 4.20, 29.69) for females, about 10-fold higher than the RR for HZE ion radiation, 3.73 (95\% CI 1.35, 10.30 ) and 0.76 (95\% CI 0.18, 3.24), respectively (Table 3). For other end points, there was a similar elevation in risk for gamma ray (relative to the unexposed group) in comparison to that for HZE ion radiation, although less pronounced (Tables 3 and 4, Supplementary Tables S2 and S3). For myeloid leukaemia, HZE ion risk in males (relative to the unexposed) was 3.73 (95\% CI 1.35, 10.30), about fourfold greater than for females, 0.76 (95\% CI 0.18 , 3.24), with slightly lower elevations for gamma-exposure (Table 3 ). There is a similar, although less pronounced pattern for soft tissue sarcoma (Table 3 ). For most other end points and radiation types, 
Table 3. Estimated Cox proportional hazards model relative risks (= hazard ratios) $(95 \% \mathrm{CI}$ ) for deaths from solid cancer, lymphoma, myeloid leukaemia and soft tissue sarcoma

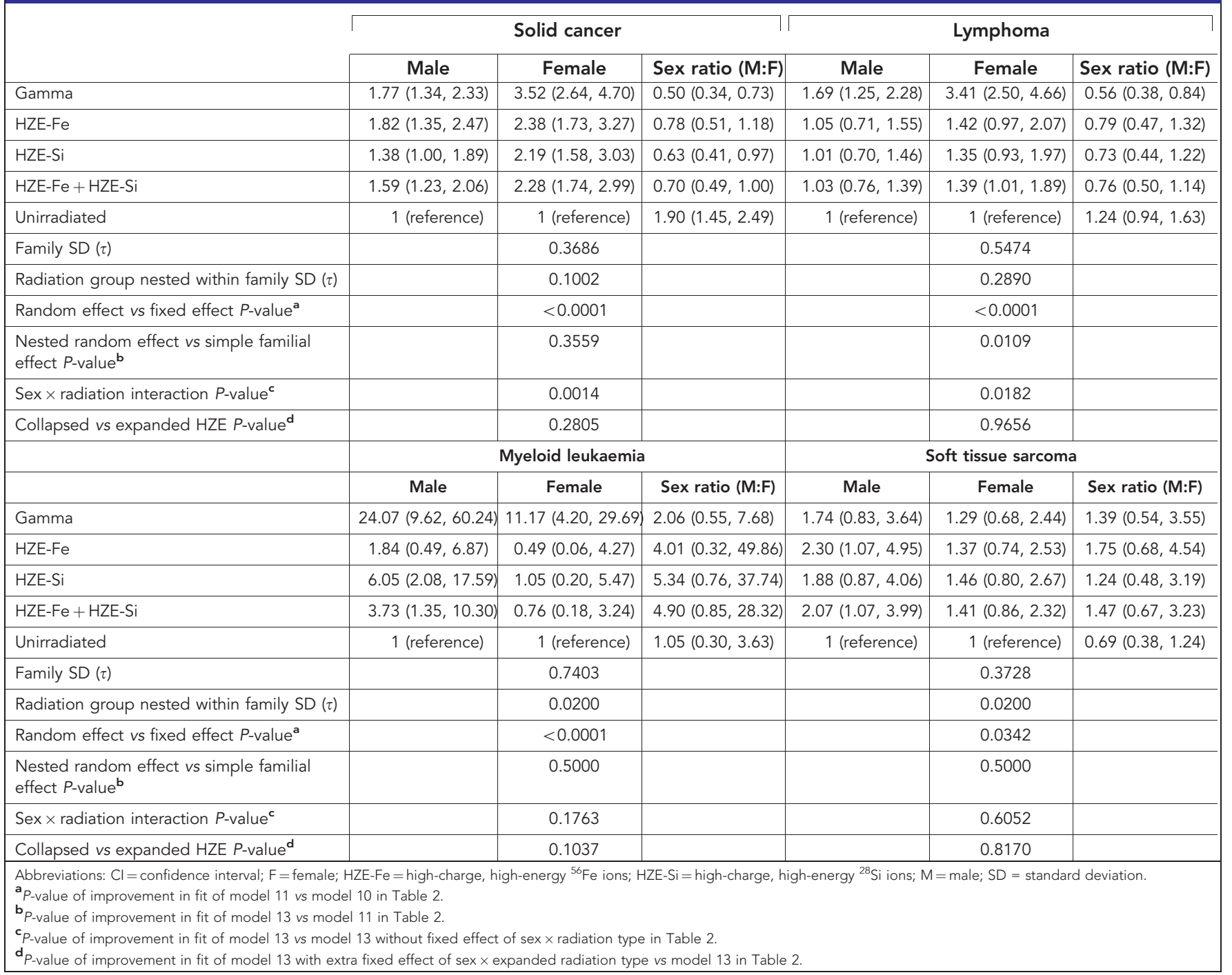

risks (relative to the unexposed) are lower in males than in females (Tables 3 and 4, Supplementary Tables S2 and S3).

Figure 1 and Supplementary Figure S4 provide distributions of estimated family-specific frailty estimates for all the cancer end points considered in this study. Family-specific frailties $>1$ indicate that the family in question is at a higher than average risk after adjusting for the effects of radiation exposure and sex. Conversely, family-specific frailties $<1$ indicate that the family in question is more resistant to radiation, after adjusting for exposure type and sex. The distributions in Figure 1 and Supplementary Figure S4 reveal a wide range of estimated family-specific frailties. For instance, in the case of all cancer deaths, frailty estimates vary between 0.56 and 1.85, with half of the estimates between 0.82 and 1.20; this range is even greater for deaths due to lymphoma and myeloid leukaemia, with frailties estimated between 0.37 and 2.80 and between 0.43 and 8.21, respectively (Figure 1). For lymphoma, myeloid leukaemia, hepatocellular carcinoma and hepatocellular adenoma, the frailty distribution is noticeably skewed to the right.

The autocorrelation plots of familial random effects in Figure 2 and Supplementary Figure S5 suggest that there are long-range correlations among the families in the circular-breeding scheme. For all end points, a periodic correlation structure is suggested, which is most striking and regular for pulmonary adenoma
$(P=0.0001)$, Harderian-gland adenoma $(P=0.0003)$, unilateral Harderian-gland tumour $(P=0.0017)$, ectodermal tumour $(P=0.0035)$, pulmonary adenocarcinoma $(P=0.0257)$ and hepatocellular carcinoma $(P=0.0340)$, with families that are three or four generations apart most strongly correlated. Although not conventionally statistically significant $(P=0.4425)$, myeloid leukaemia exhibited a striking periodic correlation structure (Figure 2), with period 4, at least for differences in familial 'distance', $m$, up to 17 ; the Fisher $g$-test evaluated over the first $m=17$ autocorrelations was significant $(P=0.0117)$ (data not shown). There are indications at borderline levels of statistical significance of periodic correlations also for all cancer $(P=0.0725$; Supplementary Figure S5).

\section{DISCUSSION}

We have shown that mice exposed to accelerated Si or Fe ions yield an increased risk of cancer and all-cause mortality. In all cases, there was no significant difference between the effects of $\mathrm{Si}$ ions and $\mathrm{Fe}$ ions, and both were somewhat less effective than ${ }^{137} \mathrm{Cs}$ gamma rays, albeit given at somewhat lower dose $(0.4 \mathrm{~Gy}$ for $\mathrm{Fe}$ 
Table 4. Estimated Cox proportional hazards model relative risks (= hazard ratios) $(95 \% \mathrm{Cl}$ ) for deaths from pulmonary adenocarcinoma, pulmonary adenoma, hepatocellular carcinoma and hepatocellular adenoma

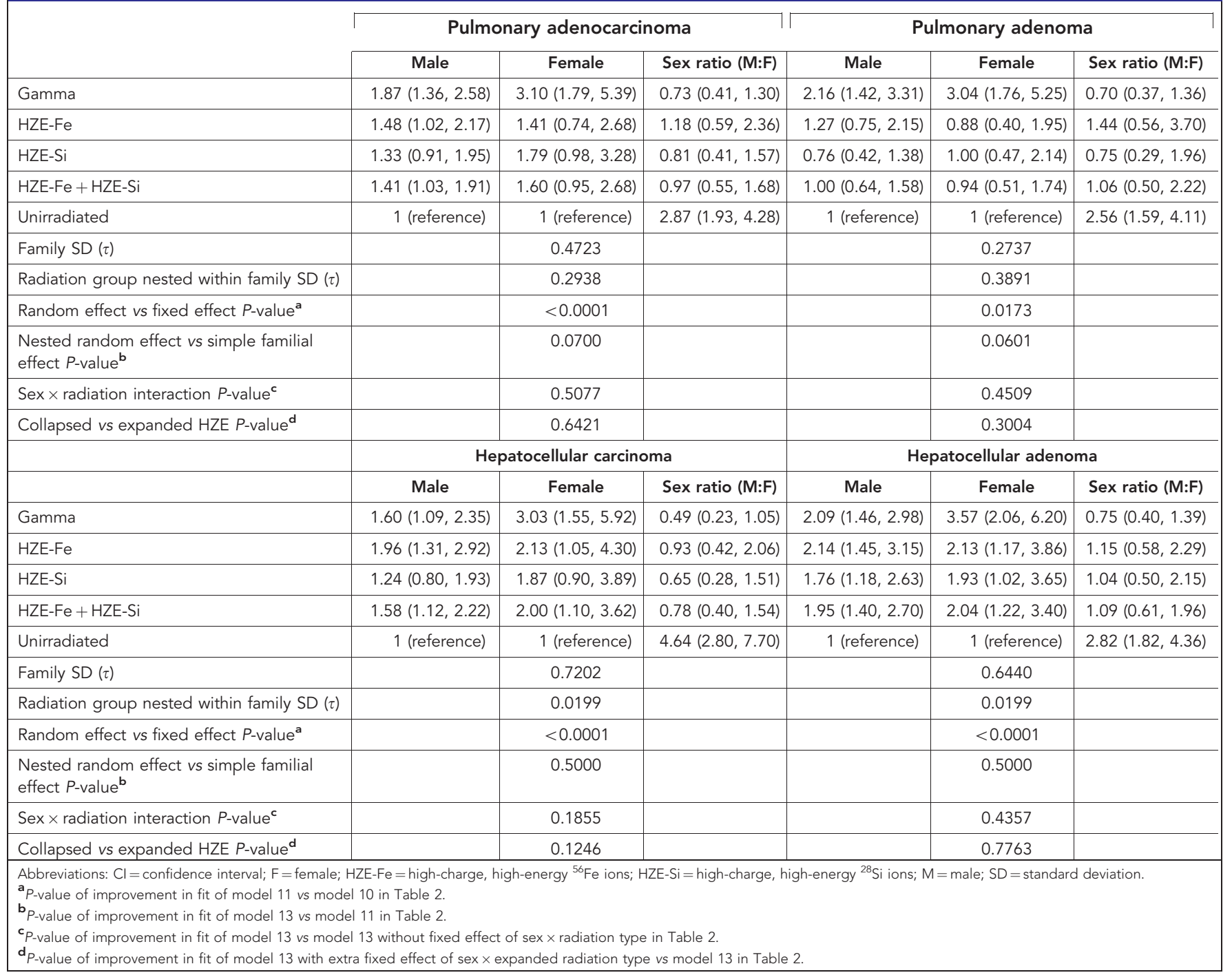

and $\mathrm{Si}$ ions $v s 3 \mathrm{~Gy}$ for gamma rays). There are significant periodic long-range correlations in familial relatedness for several malignant end points.

Mouse family had an important role in susceptibility to highenergy particles. Based on goodness-of-fit criteria (AIC), all optimal models incorporated either a nested random effect of radiation exposure within family or a non-nested random family effect; for lymphoma, all death, all cancer and mesodermal tumours, there is evidence of a more complex nested random effects structure allowing for variations in risk by radiation group within family (see equation (2)). For many end points, the interaction between sex and type of radiation exposure was statistically significant, suggesting differential sensitivity to HZE radiation by sex. There is a tendency for risks (relative to the unexposed group) to be lower in males than in females for most end points, with myeloid leukaemia and soft tissue sarcoma being the exceptions (Tables 3 and 4, Supplementary Tables S2 and S3), somewhat offsetting the elevated risks for males in the baseline (unirradiated group). For most end points and in both genders, RR were higher for gamma ray than for HZE ion radiation, with risks for both greater than for the unirradiated group; the gamma ray excess was particularly striking for myeloid leukaemia (Tables 3 and 4, Supplementary Tables S2 and S3). A limitation of the analysis is the relatively small size of the data set, although quite large for an animal study. There are about 13 animals per family in each of the radiation groups (unexposed/HZE-exposed/gammaexposed); nevertheless, because the cancer incidence is relatively high for many end points (see Table 1) these numbers are enough to furnish information on variation of tumour rate by family.

A strength of this study is the circular-breeding scheme, resulting in a genetically heterogeneous mouse population that is more similar to the outbred human population than are most experimental animal studies. It is based on a random-breeding scheme started over 20 years previously based on 8 pure-bred strains (Hitzemann et al, 1994). In a circular-breeding scheme, mice from similar family index numbers are closely related and thus should share much of their genetic information. This genetic similarity is reflected in the familial random effect, with mice from similar family index numbers having similarly large or small random effects. We also found a striking periodicity in the familial random effects, which is most pronounced for pulmonary tumours and adenomas, Harderian-gland tumours and adenomas and ectodermal tumours but suggested also for various other tumour groups (all cancer, myeloid leukaemia), with families three or four 
generations apart strongly correlated (Figure 2, Supplementary Figure S5). It is possible that the periodic pattern is indicative of chromosomal recombinations that occur every four generations on average. The mouse $\mathrm{X}$ chromosome has the lowest recombination rates compared with other chromosomes, with a recombination rate that is about three times lower than that of humans (JensenSeaman et al, 2004), suggesting that X-linked traits may exhibit long-range correlations in this species. It has been suggested that $\mathrm{X}$-linked gene reactivation may promote cancer development and progression (Chaligne and Heard, 2014). The binomial probability of $\geqslant 6$ out of the 16 independent events (in this case Fisher $g$-tests) occurring, each with probability 0.05 , is very highly significant $(P<0.0001)$; however, not all the end point groups we consider, and therefore not all the statistical tests, are statistically independent.

Quantitatively, by treating families as independent in our analysis, that is, overlooking potential similarity among 'neighbouring' families, our estimate of model variance is not optimal. Explicitly accounting for the complex correlation structure evident from Figure 2 and Supplementary Figure S5 has several inherent modelling challenges. For example, using an adjacency matrix to capture similarity between adjacent family indices would induce dependence that is too simple and thus would not accommodate the periodic correlation structure in these data. On the other hand, a geo-statistical approach, where family number is treated as a onedimensional 'coordinate', would suffer from coordinate duplication as mice within the same family would have an identical family index, that is, 'coordinates'. This would result in a variancecovariance matrix that is singular and non-invertible, preventing further analysis. Further methodological work in this area is necessary so that family indices can be optimally incorporated into statistical analyses.

There are substantial strain differences in radiogenic cancer susceptibility, in particular radiation-associated cancer susceptibility of some of the component strains. Susceptibility loci have been mapped for a number of radiogenic cancers (Demant, 2003; Darakhshan et al, 2006) and in some cases candidate sequence variants in specific genes have been identified (Mori et al, 2001; Yu et al, 2001; Rosemann et al, 2014). Those studies used recombinant congenic strains and traditional crosses between inbred strains. However, evidence for detectable genetic susceptibility to radiogenic cancers in a highly genetically diverse murine population has been lacking. Our results imply that familial differences in heterogeneous stock mice maintained with circular breeding can result in at least a twofold variation in underlying all-cause mortality, as well as for solid cancers and haematological malignancies (Figure 1, Supplementary Figure S4). The two-level random effect model that is indicated for certain end points (lymphoma, all death, all cancer, mesodermal tumours) (Tables 3 and 4, Supplementary Tables S2 and S3) suggests that there are additional random variations in the effect of each type of radiation (HZE-Fe + HZE-Si, gamma rays) within each family, implying that there is differential effectiveness of each radiation type per family. This suggests that there may be variation of radiation-associated risk with genetic background in humans, for which there is evidence for breast cancer in germline $R B 1$ heterozygous patients (Little et al, 2014), although for breast cancer risk in relation to $B R C A 1 / 2$ heterozygosity the evidence is more mixed (Pijpe et al, 2012; Bernstein et al, 2013; John et al, 2013). Familial correlations in incidence of cancer may also be connected with the welldocumented spatio-temporal clusters of childhood leukaemia and other childhood cancers (Committee on Medical Aspects of Radiation in the Environment (COMARE), 2006). At least for myeloid leukaemia in male mice, our RR, of 24.07 for gamma, of 1.84 for HZE-Fe, 6.05 for HZE-Si (Table 3), tend to be lower than those of Weil et al (2014) using mice from one of the component strains $(\mathrm{C} 3 \mathrm{H} / \mathrm{HeNCrl})$ given the same doses and types of radiation, who observed prevalence RR of 42.5 for gamma, 1.4 for HZE-Fe and 10.3 for HZE-Si. As the $\mathrm{C} 3 \mathrm{H}$ strain is known to be highly radiogenic for myeloid leukaemia (Rivina et al, 2014), the generally lower RR we found in a genetically heterogeneous mouse population are unsurprising. This suggests that risks of space radiation exposure, a large part of which is from galactic cosmicray-associated HZE ions, in outbred populations such as this one and humans may be less than for the pure-bred strains used by Weil et al (2014).

For end points other than myeloid leukaemia, the ratio of $0.8-$ 3.2 for ${ }^{137} \mathrm{Cs}$ gamma-ray RR to the combined HZE-ion RR (Tables 3 and 4, Supplementary Tables S2 and S3) implies, given the difference in mean doses $(0.4 \mathrm{~Gy}$ vs $3 \mathrm{~Gy})$, that the relative biological effectiveness (RBE) of the ${ }^{28} \mathrm{Si}$ and ${ }^{56} \mathrm{Fe} \mathrm{HZE}$ ions relative to ${ }^{137} \mathrm{Cs}$ gamma may be relatively modest, no more than about $3 /$ $(0.4 \times 3.2)-3 /(0.4 \times 0.8) \sim 2.3-8.9$ for these end points. For myeloid leukaemia, the ratio of ${ }^{137} \mathrm{Cs}$ gamma-ray $\mathrm{RR}$ to the combined HZE-ion RR is between 6.5 and 14.7 (Table 3), implying a somewhat lower RBE, of $3 /(0.4 \times 14.7)-3 /$ $(0.4 \times 6.5) \sim 0.5-1.2$. However, ideally estimation of RBE, and specifically the low dose-limiting $\mathrm{RBE}, \mathrm{RBE}_{\max }$, that is most often cited (National Council on Radiation Protection and Measurements (NCRP), 1990) requires estimation of risk after irradiation with a range of doses, particularly important given the non-linearities in dose response for some end points and inbred mouse strains (Major, 1979; Weil et al, 2014). A previous study of $\mathrm{C} 3 \mathrm{H} / \mathrm{HeNCrl}$ mice found increased incidence of lung metastases after exposure to ${ }^{28} \mathrm{Fe}$ and ${ }^{56} \mathrm{Si}$ HZE ions compared with protons and gamma radiation (Weil et al, 2014). The authors suggested that the qualitative as well as quantitative differences between these different types of radiation on neoplastic processes are consistent with ${ }^{28} \mathrm{Fe}$ and ${ }^{56} \mathrm{Si} \mathrm{HZE}$ ions inducing so-called non-DNA targeted effects (Kadhim et al, 2013), specifically as predicted by a number of studies which implied that changes in the tissue microenvironment associated with upregulation of cytokines and inflammatory pathways increases the probability of tumour progression (Grivennikov et al, 2010). This non-DNA-targeted effect was hypothesised to result specifically from these HZE ions and not from gamma ray or proton irradiation, for which a more standard target-theory model appears to apply (Weil et al, 2014). However, there is abundant evidence of non-DNA-targeted effects after a variety of types of radiation, in particular both low and high LET radiation (Kadhim et al, 2013).

Although there is little or no human data on the effects of the relatively heavy charged ion beams of the sort addressed by this study, there is emerging data on somewhat lighter high-energy charged particle beams. Proton therapy is a type of external beam radiotherapy, being used in an increasing number of radiotherapy centres around the world (Greco and Wolden, 2007). The beams used generally have energy in the range 60-250 MeV (Paganetti et $a l, 2002)$, so somewhat below the energy used here (240$600 \mathrm{MeV} \mathrm{n}^{-1}$ ). The much higher energy of such beams compared with those employed in gamma and electron beam radiotherapy means that energy deposition is relatively concentrated in tissue, with a relatively narrow spread-out Bragg peak (SOBP) (Greco and Wolden, 2007). In our experiment, the mice were positioned in the plateau region before the Bragg peak. The narrowness of the SOBP is the reason for the use of proton therapy, as tuning of the beam means that normal tissue dose can be much lower than conventional radiotherapy, in particular intensity-modulated radiotherapy. There is experimental in vitro and in vivo data for a number of end points (cell survival, acute skin reaction, epilation, etc), suggesting that the RBE of such proton beams for the SOBP relative to high-energy gamma radiation is about 1.1 (Paganetti et al, 2002); note that the dose we employ is the entrance dose, that is, before the Bragg peak, and so is not comparable. However, there are grounds for believing that the proton-beam RBE for certain end 
points may be somewhat higher, about 1.2 (Jones et al, 2012) to 1.7 (Paganetti, 2014). Even small increases in RBE for certain end points may be clinically significant (Jones et al, 2012). Although there is human data on acute normal tissue effects of proton-beam radiotherapy, the latter (cancer and cardiovascular effects) of such radiation is still unknown. The results of the present paper, in particular the approximate calculations outlined above, suggest that the magnitude of radiation-associated late health effects may not be markedly different (per unit dose), in the range 0.5-8.9, from those associated with conventional (gamma/electron beam) radiotherapy.

\section{ACKNOWLEDGEMENTS}

This work was supported by the Intramural Research Program of the National Institutes of Health, the National Cancer Institute, Division of Cancer Epidemiology and Genetics and by grant NNX12AB54G from the National Aeronautics and Space Administration. We thank the associate editor and two referees for detailed and helpful comments and Dr Diana Merino for helpful suggestions on an earlier version of this manuscript.

\section{CONFLICT OF INTEREST}

The authors declare no conflict of interest.

\section{REFERENCES}

Aalen OO (1988) Heterogeneity in survival analysis. Stat Med 7(11): $1121-1137$.

Akaike $H$ (1973) Information theory and an extension of the maximum likelihood principle. In: Petrov BN, Czáki F (eds) 2nd International Symposium on Information Theory. Akadémiai Kiadó: Budapest, Hungary, pp 267-281

Akaike H (1981) Likelihood of a model and information criteria. J Econom 16(1): 3-14

Bernstein JL, Thomas DC, Shore RE, Robson M, Boice Jr JD, Stovall M, Andersson M, Bernstein L, Malone KE, Reiner AS, Lynch CF, Capanu M, Smith SA, Tellhed L, Teraoka SN, Begg CB, Olsen JH, Mellemkjaer L, Liang X, Diep AT, Borg A, Concannon P, Haile RW (2013) Contralateral breast cancer after radiotherapy among $B R C A 1$ and $B R C A 2$ mutation carriers: A WECARE Study Report. Eur J Cancer 49(14): 2979-2985.

Bielefeldt-Ohmann H, Genik PC, Fallgren CM, Ullrich RL, Weil MM (2012) Animal studies of charged particle-induced carcinogenesis. Health Phys 103(5): 568-576.

Borch-Johnsen K, Olsen JH, Sørensen TI (1994) Genes and family environment in familial clustering of cancer. Theor Med 15(4): 377-386.

Chaligne R, Heard E (2014) X-chromosome inactivation in development and cancer. FEBS Lett 588(15): 2514-2522.

Chylack Jr. LT, Feiveson AH, Peterson LE, Tung WH, Wear ML, Marak LJ, Hardy DS, Chappell LJ, Cucinotta FA (2012) NASCA report 2:

Longitudinal study of relationship of exposure to space radiation and risk of lens opacity. Radiat Res 178(1): 25-32.

Chylack Jr. LT, Peterson LE, Feiveson AH, Wear ML, Manuel FK, Tung WH, Hardy DS, Marak LJ, Cucinotta FA (2009) NASA study of cataract in astronauts (NASCA). Report 1: Cross-sectional study of the relationship of exposure to space radiation and risk of lens opacity. Radiat Res 172(1): $10-20$

Committee on Medical Aspects of Radiation in the Environment (COMARE) (2006) Eleventh Report. The distribution of childhood leukaemia and other childhood cancer in Great Britain 1969-1993. Health Protection Agency: Chilton, UK, pp 1-160.

Cox DR (1972) Regression models and life-tables. J R Stat Soc Ser B 34(2): $187-220$.
Cox DR, Hinkley DV (1974) Theoretical Statistics. Chapman and Hall: London, UK, pp 1-511.

Crabbe Jr. JC, Young ER, Kosobud A (1983) Genetic correlations with ethanol withdrawal severity. Pharmacol Biochem Behav 18(Suppl 1): 541-547.

Darakhshan F, Badie C, Moody J, Coster M, Finnon R, Finnon P, Edwards AA, Szluinska M, Skidmore CJ, Yoshida K, Ullrich R, Cox R, Bouffler SD (2006) Evidence for complex multigenic inheritance of radiation AML susceptibility in mice revealed using a surrogate phenotypic assay. Carcinogenesis 27(2): 311-318.

Demant P (2003) Cancer susceptibility in the mouse: genetics, biology and implications for human cancer. Nat Rev Genet 4(9): 721-734.

Durante M, Cucinotta FA (2008) Heavy ion carcinogenesis and human space exploration. Nat Rev Cancer 8(6): 465-472.

Egawa H, Furukawa K, Preston D, Funamoto S, Yonehara S, Matsuo T, Tokuoka S, Suyama A, Ozasa K, Kodama K, Mabuchi K (2012) Radiation and smoking effects on lung cancer incidence by histological types among atomic bomb survivors. Radiat Res 178: 191-201.

Fisher RA (1929) Tests of significance in harmonic analysis. Proc R Soc Lond Ser A 125(796): 54-59.

Folley JH, Borges W, Yamawaki T (1952) Incidence of leukemia in survivors of the atomic bomb in Hiroshima and Nagasaki, Japan. Am J Med 13(3): 311-321.

Gazdar A, Robinson L, Oliver D, Xing C, Travis WD, Soh J, Toyooka S, Watumull L, Xie Y, Kernstine K, Schiller JH (2014) Hereditary lung cancer syndrome targets never smokers with germline EGFR gene T790M mutations. J Thorac Oncol 9(4): 456-463.

Gonzalez KD, Noltner KA, Buzin CH, Gu D, Wen-Fong CY, Nguyen VQ, Han JH, Lowstuter K, Longmate J, Sommer SS, Weitzel JN (2009) Beyond Li Fraumeni Syndrome: clinical characteristics of families with $p 53$ germline mutations. J Clin Oncol 27(8): 1250-1256.

Greco C, Wolden S (2007) Current status of radiotherapy with proton and light ion beams. Cancer 109(7): 1227-1238.

Grivennikov SI, Greten FR, Karin M (2010) Immunity, inflammation, and cancer. Cell 140(6): 883-899.

Hitzemann B, Dains K, Kanes S, Hitzemann R (1994) Further studies on the relationship between dopamine cell density and haloperidol-induced catalepsy. J Pharmacol Exp Ther 271(2): 969-976.

Hsu W-L, Preston DL, Soda M, Sugiyama H, Funamoto S, Kodama K, Kimura A, Kamada N, Dohy H, Tomonaga M, Iwanaga M, Miyazaki Y, Cullings HM, Suyama A, Ozasa K, Shore RE, Mabuchi K (2013) The incidence of leukemia, lymphoma and multiple myeloma among atomic bomb survivors: 1950-2001. Radiat Res 179(3): 361-382.

Jensen-Seaman MI, Furey TS, Payseur BA, Lu Y, Roskin KM, Chen C-F, Thomas MA, Haussler D, Jacob HJ (2004) Comparative recombination rates in the rat, mouse, and human genomes. Genome Res 14(4): 528-538.

John EM, McGuire V, Thomas D, Haile R, Ozcelik H, Milne RL, Felberg A, West DW, Miron A, Knight JA, Terry MB, Daly M, Buys SS, Andrulis IL, Hopper JL, Southey MC, Giles GG, Apicella C, Thorne H, Whittemore AS (2013) Diagnostic chest X-rays and breast cancer risk before age 50 years for BRCA1 and BRCA2 mutation carriers. Cancer Epidemiol Biomarkers Prev 22(9): 1547-1556.

Jones B, Wilson P, Nagano A, Fenwick J, McKenna G (2012) Dilemmas concerning dose distribution and the influence of relative biological effect in proton beam therapy of medulloblastoma. Br J Radiol 85(1018): e912-e918.

Kadhim M, Salomaa S, Wright E, Hildebrandt G, Belyakov OV, Prise KM, Little MP (2013) Non-targeted effects of ionising radiation-implications for low dose risk. Mutat Res 752(2): 84-98.

Kendall GM, Little MP, Wakeford R, Bunch KJ, Miles JCH, Vincent TJ, Meara JR, Murphy MFG (2013) A record-based case-control study of natural background radiation and the incidence of childhood leukaemia and other cancers in Great Britain during 1980-2006. Leukemia 27(1): 3-9.

Leuraud K, Richardson DB, Cardis E, Daniels RD, Gillies M, O’Hagan JA, Hamra GB, Haylock R, Laurier D, Moissonnier M, Schubauer-Berigan MK, Thierry-Chef I, Kesminiene A (2015) Ionising radiation and risk of death from leukaemia and lymphoma in radiation-monitored workers (INWORKS): an international cohort study. Lancet Haematol 2(7): e276-e281.

Little MP, Schaeffer ML, Reulen RC, Abramson DH, Stovall M, Weathers R, de Vathaire F, Diallo I, Seddon JM, Hawkins MM, Tucker MA, Kleinerman RA (2014) Breast cancer risk after radiotherapy for heritable 
and non-heritable retinoblastoma: a US-UK study. Br J Cancer 110(10): 2623-2632.

Major IR (1979) Induction of myeloid leukaemia by whole-body single exposure of CBA male mice to x-rays. Br J Cancer 40(6): 903-913.

McDuffie HH (1991) Clustering of cancer in families of patients with primary lung cancer. J Clin Epidemiol 44(1): 69-76.

Mori N, Matsumoto Y, Okumoto M, Suzuki N, Yamate J (2001) Variations in Prkdc encoding the catalytic subunit of DNA-dependent protein kinase (DNA-PKcs) and susceptibility to radiation-induced apoptosis and lymphomagenesis. Oncogene 20(28): 3609-3619.

Nagy R, Sweet K, Eng C (2004) Highly penetrant hereditary cancer syndromes. Oncogene 23(38): 6445-6470.

National Council on Radiation Protection and Measurements (NCRP) (1990) Report No. 104. The Relative Biological Effectiveness of Radiations of Different Quality. pp 1-218. NCRP: Bethesda, MD, USA.

Nickels EM, Soodalter J, Churpek JE, Godley LA (2013) Recognizing familial myeloid leukemia in adults. Ther Adv Hematol 4(4): 254-269.

Paganetti H (2014) Relative biological effectiveness (RBE) values for proton beam therapy. Variations as a function of biological endpoint, dose, and linear energy transfer. Phys Med Biol 59(22): R419-R472.

Paganetti H, Niemierko A, Ancukiewicz M, Gerweck LE, Goitein M, Loeffler JS, Suit HD (2002) Relative biological effectiveness (RBE) values for proton beam therapy. Int J Radiat Oncol Biol Phys 53(2): 407-421.

Pearce MS, Salotti JA, Little MP, McHugh K, Lee C, Kim KP, Howe NL, Ronckers CM, Rajaraman P, Craft AW, Parker L, Berrington de González A (2012) Radiation exposure from CT scans in childhood and subsequent risk of leukaemia and brain tumours: a retrospective cohort study. Lancet 380(9840): 499-505.

Pijpe A, Andrieu N, Easton DF, Kesminiene A, Cardis E, Noguès C, Gauthier-Villars M, Lasset C, Fricker J-P, Peock S, Frost D, Evans DG, Eeles RA, Paterson J, Manders P, van Asperen CJ, Ausems MGEM, Meijers-Heijboer H, Thierry-Chef I, Hauptmann M, Goldgar D, Rookus MA, van Leeuwen FE (2012) Exposure to diagnostic radiation and risk of breast cancer among carriers of BRCA1/2 mutations: retrospective cohort study (GENE-RAD-RISK). BMJ 345: e5660.

R Core Team. (2015) R: A Language and Environment for Statistical Computing. R Project version 3.2.2. Comprehensive R Archive Network (CRAN). R Core Team: Vienna, Austria. http://www.r-project.org/.

Ripatti S, Palmgren J (2000) Estimation of multivariate frailty models using penalized partial likelihood. Biometrics 56(4): 1016-1022.

Rivina L, Davoren M, Schiestl RH (2014) Radiation-induced myeloid leukemia in murine models. Hum Genomics 8: 13.

Rosemann M, Gonzalez-Vasconcellos I, Domke T, Kuosaite V, Schneider R, Kremer M, Favor J, Nathrath M, Atkinson MJ (2014) A Rbl promoter variant with reduced activity contributes to osteosarcoma susceptibility in irradiated mice. Mol Cancer 13: 182.

Schwarz G (1978) Estimating the dimension of a model. Ann Stat 6(2): 461-464.

Seif AE (2011) Pediatric leukemia predisposition syndromes: clues to understanding leukemogenesis. Cancer Genet 204(5): 227-244.

Self SG, Liang K-Y (1987) Asymptotic properties of maximum likelihood estimators and likelihood ratio tests under nonstandard conditions. J Am Stat Assoc 82(398): 605-610.

Sridharan DM, Chappell LJM, Whalen MK, Cucinotta FA, Pluth JM (2015) Defining the biological effectiveness of components of high-LET track structure. Radiat Res 184(1): 105-119.

Storer JB, Mitchell TJ, Fry RJM (1988) Extrapolation of the relative risk of radiogenic neoplasms across mouse strains and to man. Radiat Res 114(2): 331-353.

Therneau TM (2015) coxme: Mixed effects Cox models. Version 2.2-5: CRAN-The Comprehensive R Archive Network. R Core Team, Vienna, Austria.

United Nations Scientific Committee on the Effects of Atomic Radiation (UNSCEAR) (2008) UNSCEAR 2006 Report. Annex A. Epidemiological Studies of Radiation and Cancer. United Nations: New York, USA, pp 13-322.

Vaupel JW, Manton KG, Stallard E (1979) The impact of heterogeneity in individual frailty on the dynamics of mortality. Demography 16(3): 439-454.

Weil MM, Bedford JS, Bielefeldt-Ohmann H, Ray FA, Genik PC, Ehrhart EJ, Fallgren CM, Hailu F, Battaglia CLR, Charles B, Callan MA, Ullrich RL (2009) Incidence of acute myeloid leukemia and hepatocellular carcinoma in mice irradiated with $1 \mathrm{GeV} /$ nucleon ${ }^{56} \mathrm{Fe}$ ions. Radiat Res 172(2): 213 219.

Weil MM, Ray FA, Genik PC, Yu Y, McCarthy M, Fallgren CM, Ullrich RL (2014) Effects of ${ }^{28} \mathrm{Si}$ ions, ${ }^{56} \mathrm{Fe}$ ions, and protons on the induction of murine acute myeloid leukemia and hepatocellular carcinoma. PLOS ONE 9(7): e104819.

Yu Y, Okayasu R, Weil MM, Silver A, McCarthy M, Zabriskie R, Long S, Cox R, Ullrich RL (2001) Elevated breast cancer risk in irradiated BALB/c mice associates with unique functional polymorphism of the Prkdc (DNA-dependent protein kinase catalytic subunit) gene. Cancer Res 61(5): 1820-1824.

This work is published under the standard license to publish agreement. After 12 months the work will become freely available and the license terms will switch to a Creative Commons AttributionNonCommercial-Share Alike 4.0 Unported License.

Supplementary Information accompanies this paper on British Journal of Cancer website (http://www.nature.com/bjc) 